\title{
Fungal diversity rather than bacterial diversity drives the ecosystem multifunctionality of vineyards in a semi-arid region
}

\author{
Bingbing Duan ${ }^{1}$, Yizhao Ren ${ }^{1,2}$, Leqi Zhang ${ }^{1}$, Chenxing Suzhou ${ }^{1}$, Guoqiao Chen ${ }^{1}$, Ping Cui ${ }^{3}$, \\ Yusong Zhangyang ${ }^{1}$, Wei Liu ${ }^{4}$, Hasmik Merkeryan ${ }^{1}$, Xu Liu ${ }^{1,5^{*}}$ \\ (1. College of Enology, Northwest A\&F University, Yangling 712100, Shaanxi, China; \\ 2. Penglai Wine College, Yantai Institute of Science and Technology, Yantai 265600, Shandong, China; \\ 3. Grape Industrial Park Management Committee of the Eastern Foot of Helan Mountain in Ningxia, Yinchuan 750004, China; \\ 4. Horticulture Research Institute, Sichuan Academy of Agricultural Sciences, Chengdu 610066, China;
}

5. Ningxia Helan Mountain's East Foothill Wine Experiment and Demonstration Station of Northwest A\&F University, Yongning 750104, Ningxia, China)

\begin{abstract}
The presence of multiple ecosystem functions and services (i.e., ecosystem multifunctionality) has been proven to be maintained by biodiversity in natural terrestrial ecosystems. However, the mechanisms by which microbial diversity drives ecosystem functions in vineyards and the effects of ecosystem functions on wine quality remain unknown. Here, fifteen vineyards from five wine sub-regions (Shizuishan, Yinchuan, Yuquanying, Qingtongxia, and Hongsipu) in Ningxia were selected to assess the microbial community structure, ecosystem multifunctionality, and wine quality. Overall, each index differed among the vineyards from these five wine sub-regions in Ningxia. High-throughput sequencing revealed that bacterial and fungal communities varied among these vineyards. Bacterial communities were dominated by Actinobacteria, Proteobacteria, Chloroflexi, and Acidobacteria. Ascomycota was the dominant fungal phylum, followed by Basidiomycota and Mortierellomycota. In addition, fungal Shannon diversity rather than bacterial Shannon diversity showed a positive relationship with ecosystem multifunctionality. Correlation analysis revealed that ecosystem multifunctionality was positively correlated with wine acidity and negatively correlated with $\mathrm{pH}$ value and residual sugar content of wine. Soil chemical functions exhibited relationships with wine quality being similar to those of ecosystem multifunctionality; i.e., positively related to wine acidity but negatively related to wine $\mathrm{pH}$ and residual sugar content. However, soil physical functions were negatively correlated with the alcohol and anthocyanin content of wine. The research results show that the ecosystem functions maintained by fungal diversity could be attributed to wine quality of vineyards.
\end{abstract}

Keywords: microbial diversity, multifunctionality, terroir, wine quality, wine sub-regions

DOI: $10.25165 /$ j.ijabe. 20211406.5560

Citation: Duan B B, Ren Y Z, Zhang L Q, Suzhou C X, Chen G Q, Cui P, et al. Fungal diversity rather than bacterial diversity drives the ecosystem multifunctionality of vineyards in a semi-arid region. Int J Agric \& Biol Eng, 2021; 14(6): $126-136$.

\section{Introduction}

Multiple ecosystem functions and services (i.e., multifunctionality) as opposed to a single ecosystem function, such as net primary productivity or nutrient cycling, reflect the combinations of functions of terrestrial ecosystems and the tradeoffs among them ${ }^{[1-4]}$. Biodiversity plays a vital role in

\section{Received date: 2020-11-21 Accepted date: 2021-11-09}

Biographies: Bingbing Duan, $\mathrm{PhD}$ candidate, research interest: grape physiology, Email: duanbb@nwafu.edu.cn; Yizhao Ren, MS, research interests: vineyard soil management, Email: renyizhao123@nwafu.edu.cn; Leqi Zhang, MS, research interests: grape berry chemistry, Email: 313144470@qq.com; Chenxing Suzhou, $\mathrm{PhD}$ candidate, research interests: vineyard soil microecology, Email: anthozhou@foxmail.com; Guoqiao Chen, MS, research interests: microbial community diversity, Email: qiaoguochen1998@163.com; Ping Cui, BS, Researcher, research interests: terroir and climatic regionalization; Email: 564539085@qq.com; Yusong Zhangyang, MS, research interests: vineyard terroir, Email: 985164815@qq.com; Wei Liu, PhD, Associate Researcher, research interests: viticulture, Email: 28242291@qq.com; Hasmik Merkeryan, $\mathrm{PhD}$ candidate, research interests: sensory science of wine, Email: merkeryan.hasmik@gmail.com.

*Corresponding author: $\mathbf{X u ~ L i u , ~} \mathrm{PhD}$, Associate Professor, research interest: viticulture and terroir. College of Enology, Northwest A\&F University, Yangling 712100, Shaanxi, China. Tel: +86-29-87092598, Email: liuxu@nwafu.edu.cn. maintaining ecosystem functions. Previous studies have indicated that high diversity of organisms at each trophic level in a food web participating in biogeochemical cycling and energy flow promote the existence of multiple ecosystem functions ${ }^{[5-8]}$. Some investigations have found plant diversity to be positively related to ecosystem multifunctionality in natural terrestrial ecosystems ${ }^{[9,10]}$. Soil microbes, playing vital roles in nutrient cycling and the formation of soil structure in terrestrial ecosystems, have been reported to promote multiple functions in terrestrial ecosystems ${ }^{[11-13]}$. However, agroecosystems manipulated by humans show characteristics that differ from those of natural ecosystems, such as monoculture, meaning low diversity of plants and products exported from agroecosystems. Practices such as fertilization and irrigation conducted in agroecosystems also disturb microbial community structure and diversity. A recent study conducted in farmland revealed that long-term organic fertilizer improved soil multifunctionality by increasing bacterial and fungal diversity. However, none of these studies have focused on how soil microbial diversity would drive multifunctionality of the wine sub-regions in northwest China.

Suitable soil conditions can meet the requirements of fruit-producing plants for water, nutrients, and temperature and thus improve the yield and quality of fruits. Soil nutrient contents 
are the most important factors affecting grape growth and quality. Moreover, grape berry quality determines the quality of the resulting wine and is affected by soil conditions. For example, soil rich in organic matter leads to darker grape skin and higher tannin contents ${ }^{[14]}$. Soil rich in phosphorus $(\mathrm{P})$ is helpful for the synthesis of anthocyanins in grape $\operatorname{skin}^{[14]}$. Some studies have also shown that macronutrients and micronutrients can promote the quality of grape berries and the resulting wine; for instance, higher content of potassium $(\mathrm{K})$ in soil is beneficial for increasing the contents of total phenols and tannins in grapes ${ }^{[15,16]}$. Wine quality differs when grapes are harvested in different regions based on soil water content ${ }^{[17]}$. In vineyards of semiarid and arid regions, soil water holding capacity affected by soil texture has thus been found to influence vine water status and growth, yield, and wine quality ${ }^{[17]}$. Therefore, aspects of soil multifunctionality, including soil structure, nutrient contents, $\mathrm{pH}$ and other internal factors of the soil itself, affect the growth and development of berries and thus the quality of grape and wine $\mathrm{e}^{[18,19]}$. In addition, photosynthesis, which is affected by chlorophyll, directly influences grape formation, yield, and quality ${ }^{[20]}$. Sucrose, the product of photosynthesis, is transported through vines and stored in grape berries, thus reflecting the influence of photosynthesis on wine quality. Therefore, exploring the relationship between ecosystem multifunctionality and wine quality is of great significance for accurate vineyard management, improving wine quality and increasing farmer income.

The wine industry has developed rapidly in Ningxia of China in recent years. This region is a representative wine grape-producing area in China and enjoys a high reputation globally. At present, the area planted in wine grapes has reached $38000 \mathrm{hm}^{2}$, and the annual production of wine is 130 million bottles, which has supported 120000 ecological immigrants. Vitis vinifera $\mathrm{L}$. cv. Cabernet Sauvignon is the main commercial wine grape variety in Ningxia ${ }^{[21]}$. Overall, the different qualities of wine from different wine sub-regions in Ningxia are caused by external factors, such as soil conditions. However, knowledge about the relationships between microbial diversity and ecosystem multifunctionality of vineyards remains lacking, and the mechanisms by which ecosystem multifunctionality affects the quality of grape berries and the resulting wine remain to be explored. Herein, it was hypothesized that: 1) microbial community diversity and composition, ecosystem multifunctionality and wine quality vary among vineyards from different locations; 2) bacterial and fungal diversity drive ecosystem multifunctionality of these vineyards; and 3) changes in the quality of wine from these vineyards can be attributed to ecosystem multifunctionality.

\section{Materials and methods}

\subsection{Site description}

The experiment was conducted at the eastern foot of Helan Mountain in the Ningxia Autonomous Region of China. Five main wine sub-regions in this area were selected (Shizuishan, Yinchuan, Yuquanying, Qingtongxia, and Hongsipu) for investigation of the grape cultivar Vitis vinifera L. cv. Cabernet Sauvignon. The soil is montane grey-cinnamon soil. The climate is semiarid, with a mean annual precipitation of $225 \mathrm{~mm}$ and a mean annual temperature of $9.3^{\circ} \mathrm{C}$.

\subsection{Experimental design and sampling}

Fifteen vineyards were chosen from the five wine sub-regions. Two vineyards, named Xiyuwangquan (XYWQ) and Hedong (HED), are in the Shizuishan region. Three vineyards, named
Guanlan (GL), Helu (HL), and Zhangyu (ZY), are in Yinchuan region. Four vineyards, named Lilan (LL), Xixiawang (XXW), Baolelijia (BLLJ), and Bagesi (BGS), are in Yuquanying region. Three vineyards, named Yuhuang (YH), Yuma (YM), and Xige (XG), are in Qingtongxia region. Three vineyards, named Huida (HD), Hongfenjiarong (HFJR), and Luoshan (LS), are in Hongsipu region (Figure 1). Three sites were sampled from each vineyard, with at least $5 \mathrm{~m}$ distance between any two sites. The soil and vines were sampled during August 2019. Soil cores from three randomly selected points at each site were sampled from the 0-20 $\mathrm{cm}$ layers and combined to form composite samples. After removing stones and roots manually, all fresh soil samples were sieved through a $2 \mathrm{~mm}$ mesh. The sieved soil samples were separated into two subsamples, with one subsample being air-dried and then sieved through a $0.25 \mathrm{~mm}$ mesh to determine soil chemical and physical properties. Another subsample stored at $-80^{\circ} \mathrm{C}$ was used for high-throughput sequencing. Fifteen kilograms of grapes at commercial maturation were randomly harvested from each vineyard for berry quality determination and for making wine in small $(20 \mathrm{~L})$ glass containers.

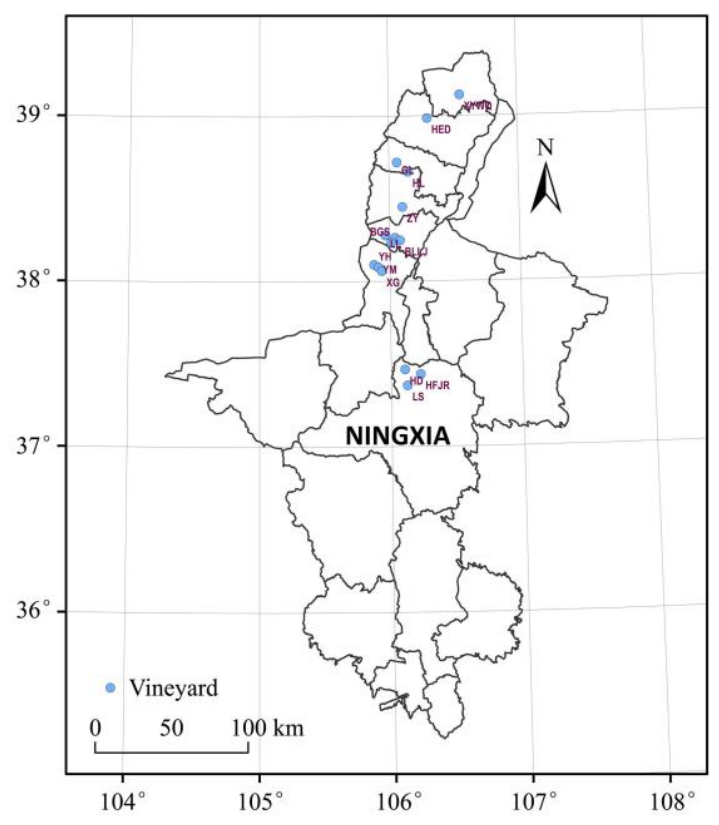

Note: Xiyuwangquan (XYWQ) and Hedong (HED) are from Shizuishan region Guanlan (GL), Helu (HL), and Zhangyu (ZY) are from Yinchuan region. Lilan (LL), Xixiawang (XXW), Baolelijia (BLLJ), and Bagesi (BGS) are from Yuquanying region. Yuhuang (YH), Yuma (YM), and Xige (XG) are from Qingtongxia region. Huida (HD), Hongfenjiarong (HFJR), and Luoshan (LS) are from Hongsipu region.

Figure 1 Distribution of fifteen vineyards

\subsection{Soil variable analyses}

The soil organic carbon (SOC) content was determined using dichromate oxidation. Soil total nitrogen (TN) content was determined using an automatic Kjeldahl instrument (Kjeltec 8400, FOSS Corporation, Denmark) ${ }^{[22]}$. Soil total phosphorus (TP) content was measured colorimetrically after being digested with $\mathrm{H}_{2} \mathrm{SO}_{4}$ and $\mathrm{HClO}_{4}{ }^{[23]}$. Soil total potassium (TK) content was measured by the $\mathrm{NaOH}$ fusion method with atomic absorption spectroscopy (GGK-830, Haiguang Instrument Co., Beijing, China). Soil available phosphorus (aP) content was determined using the Olsen method. The contents of nitrate nitrogen $\left(\mathrm{NO}_{3}^{-}-\mathrm{N}\right)$ and ammonium nitrogen $\left(\mathrm{NH}_{4}{ }^{+}-\mathrm{N}\right)$ extracted by $2 \mathrm{~mol} / \mathrm{L} \mathrm{KCl}$ were determined with a continuous-flow autoanalyzer (Alpkem, OI Analytical, USA), and soil available potassium (aK) content was determined by flame photometry. The soil $\mathrm{pH}$ was determined 
using a soil-to-water ratio of 1:2.5. The soil moisture was measured using the oven-drying method. Soil bulk density was determined by the cutting ring method. Detailed data on the soil physicochemical properties are shown in Table 1.

Table 1 Soil physicochemical property of fifteen vineyards

\begin{tabular}{|c|c|c|c|c|c|c|c|c|c|c|c|}
\hline ard & $\begin{array}{c}\mathrm{SOC} \\
\mathrm{lg} \cdot \mathrm{kg}^{-1}\end{array}$ & $\mathrm{TN} / \mathrm{mg} \cdot \mathrm{kg}^{-1}$ & $\mathrm{TP} / \mathrm{mg} \cdot \mathrm{kg}^{-1}$ & $\mathrm{TK} / \mathrm{mg} \cdot \mathrm{kg}^{-1}$ & $\begin{array}{l}\mathrm{NO}_{3}^{-}-\mathrm{N} \\
/ \mathrm{mg} \cdot \mathrm{kg}^{-1}\end{array}$ & $\begin{array}{l}\mathrm{NH}_{4}{ }^{+}-\mathrm{N} \\
/ \mathrm{mg} \cdot \mathrm{kg}^{-1}\end{array}$ & $\mathrm{P} / \mathrm{mg} \cdot \mathrm{kg}^{-1}$ & $\mathrm{aK} / \mathrm{mg} \cdot \mathrm{kg}^{-1}$ & $\mathrm{pH}$ & $\begin{array}{l}\text { Soil water } \\
\text { content } / \%\end{array}$ & $\begin{array}{c}\text { Soil bulk } \\
\text { density/g. } \mathrm{cm}^{-3}\end{array}$ \\
\hline XYWQ & $7.42 \pm 0.09^{\mathrm{ab}}$ & $578.07 \pm 98.44^{\mathrm{bc}}$ & $16.16 \pm 19.25^{\mathrm{de}}$ & $67.97 \pm 3.00^{\mathrm{cd}}$ & $75.43 \pm 4.00^{\mathrm{a}}$ & $1.19 \pm 0.13$ & (5) & $304.50 \pm 32.14$ & $1.43 \pm 0.20$ & $5.06 \pm 1.00^{\text {efg }}$ & $1.01 \pm 0.00$ \\
\hline HED & $3.88 \pm 1.92^{\mathrm{efg}}$ & $165.82 \pm 156.54^{\mathrm{ef}}$ & $184.34 \pm 10.74^{\mathrm{a}}$ & $3.10 \pm 2.80^{\mathrm{cd}}$ & $20.68 \pm 0.81^{\mathrm{cd}}$ & $0.80 \pm 0.10^{\mathrm{c}}$ & $29.71 \pm 5.79^{\mathrm{cd}}$ & $408.33 \pm 19.25^{\mathrm{c}}$ & $.18 \pm 0.32^{\mathrm{abcd}}$ & $0.19 \pm 0.65^{\mathrm{a}}$ & $1.66 \pm 0.12^{\mathrm{abcd}}$ \\
\hline GL & $6.67 \pm 0.44^{\mathrm{b}}$ & $519.66 \pm 87.18^{\mathrm{c}}$ & $102.20 \pm 10.32^{\text {ef }}$ & $38.80 \pm 1.210^{\mathrm{g}}$ & $18.77 \pm 6.44^{\mathrm{d}}$ & $0.92 \pm 0.27^{\mathrm{bc}}$ & $8.25 \pm 1.58^{\mathrm{gh}}$ & $211.83 \pm 8.96^{\mathrm{f}}$ & $8.10 \pm 0.11^{\text {bcde }}$ & $4.27 \pm 0.84^{\mathrm{gh}}$ & $1.54 \pm 0.03^{\text {cde }}$ \\
\hline HL & $7.10 \pm 0.29^{\mathrm{ab}}$ & $666.10 \pm 72.03^{\mathrm{ab}}$ & $162.01 \pm 10.37^{\mathrm{abc}}$ & $14.83 \pm 1.70^{\mathrm{i}}$ & $11.42 \pm 0.86^{\mathrm{ef}}$ & $1.02 \pm 0.15^{\mathrm{bc}}$ & $59.68 \pm 1.87^{\mathrm{a}}$ & $217.00 \pm 41.36^{\mathrm{f}}$ & $8.51 \pm 0.02^{\mathrm{a}}$ & $7.02 \pm 0.28^{\mathrm{bc}}$ & $1.55 \pm 0.17^{\text {bcde }}$ \\
\hline $\mathrm{ZY}$ & $7.95 \pm 0.93^{\mathrm{a}}$ & $787.49 \pm 133.36^{\mathrm{a}}$ & $167.05 \pm 32.28^{\mathrm{ab}}$ & $55.63 \pm 5.54^{\mathrm{e}}$ & $22.43 \pm 3.23^{\mathrm{cd}}$ & $1.65 \pm 0.64^{\mathrm{ab}}$ & $28.61 \pm 6.24^{\mathrm{d}}$ & $547.17 \pm 37.03^{b}$ & $8.32 \pm 0.20^{\mathrm{abc}}$ & $6.20 \pm 0.07^{\mathrm{cd}}$ & $1.71 \pm 0.01^{\mathrm{abc}}$ \\
\hline LL & $4.04 \pm 0.45^{\mathrm{ef}}$ & $149.17 \pm 10.26^{\mathrm{ef}}$ & $90.16 \pm 1.87^{\text {efg }}$ & $25.37 \pm 1.51^{\mathrm{h}}$ & $25.44 \pm 7.15^{\mathrm{c}}$ & $0.64 \pm 0.20^{\mathrm{c}}$ & $10.62 \pm 0.65^{\text {fgh }}$ & $705.83 \pm 18.95^{\mathrm{a}}$ & $7.96 \pm 0.14^{\text {cde }}$ & $3.86 \pm 0.39^{\mathrm{h}}$ & $1.77 \pm 0.05^{\mathrm{a}}$ \\
\hline XXW & $3.94 \pm 0.67^{\text {efg }}$ & $376.45 \pm 44.95^{\mathrm{d}}$ & $83.26 \pm 18.29^{\mathrm{fg}}$ & $98.77 \pm 1.10^{\mathrm{a}}$ & $4.76 \pm 0.04^{\mathrm{g}}$ & $0.61 \pm 0.09^{\mathrm{c}}$ & $16.84 \pm 3.93^{\text {efg }}$ & $122.50 \pm 21.28^{\mathrm{g}}$ & $8.50 \pm 0.26^{\mathrm{a}}$ & $1.55 \pm 0.19^{\mathrm{i}}$ & $1.55 \pm 0.04^{\text {bcde }}$ \\
\hline BLLJ & $7.23 \pm 0.48^{\mathrm{ab}}$ & $218.63 \pm 35.95^{\mathrm{ef}}$ & $139.38 \pm 12.41^{\mathrm{cd}}$ & $53.367 \pm 3.43^{\mathrm{e}}$ & $5.68 \pm 2.30^{\mathrm{fg}}$ & $1.15 \pm 0.51^{\mathrm{abc}}$ & $20.78 \pm 3.20^{\text {def }}$ & $243.50 \pm 39.78^{\mathrm{f}}$ & $8.16 \pm 0.13^{\text {abcde }}$ & $4.78 \pm 0.72^{\text {fgh }}$ & $1.61 \pm 0.17^{\text {abcde }}$ \\
\hline BGS & $4.94 \pm 0.45^{\mathrm{cd}}$ & $625.94 \pm 60.85^{\mathrm{bc}}$ & $145.34 \pm 14.19^{\mathrm{bc}}$ & $40.03 \pm 6.91^{\mathrm{fg}}$ & $38.18 \pm 5.35^{\mathrm{b}}$ & $1.02 \pm 0.02^{\mathrm{bc}}$ & $16.36 \pm 0.77^{\mathrm{efg}}$ & $231.83 \pm 28.10^{\mathrm{f}}$ & $7.87 \pm 0.45^{\mathrm{de}}$ & $5.50 \pm 0.45^{\mathrm{def}}$ & $1.56 \pm 0.03^{\text {bcde }}$ \\
\hline $\mathrm{YH}$ & $3.05 \pm 0.89^{\text {gh }}$ & $250.67 \pm 124.69^{\mathrm{de}}$ & $51.87 \pm 9.32^{\mathrm{h}}$ & $25.17 \pm 5.16^{\mathrm{h}}$ & $3.46 \pm 0.65^{\mathrm{g}}$ & $0.85 \pm 0.15^{\mathrm{c}}$ & $10.20 \pm 0.74^{\text {fgh }}$ & $113.08 \pm 17.88^{\mathrm{g}}$ & $8.27 \pm 0.06^{\mathrm{abc}}$ & $5.93 \pm 0.56^{\mathrm{de}}$ & $1.73 \pm 0.12^{\mathrm{ab}}$ \\
\hline YM & $5.59 \pm 0.59^{c}$ & $625.46 \pm 112.92^{\mathrm{bc}}$ & $135.21 \pm 26.47^{\mathrm{cd}}$ & $85.97 \pm 5.16^{\mathrm{b}}$ & $19.30 \pm 2.27^{\mathrm{d}}$ & $1.00 \pm 0.39^{\mathrm{bc}}$ & $40.29 \pm 16.96^{\mathrm{b}}$ & $391.67 \pm 14.49^{\mathrm{cd}}$ & $8.14 \pm 0.11^{\text {abcde }}$ & $4.51 \pm 0.26^{\mathrm{fgh}}$ & $1.52 \pm 0.07^{\mathrm{de}}$ \\
\hline $\mathrm{HD}$ & $3.49 \pm 0.35^{\mathrm{fg}}$ & $369.04 \pm 126.13^{\mathrm{d}}$ & $79.47 \pm 9.03^{\mathrm{fg}}$ & $45.60 \pm 2.13^{\mathrm{f}}$ & $2.76 \pm 0.29^{\mathrm{g}}$ & $1.28 \pm 0.63^{\mathrm{abc}}$ & $39.36 \pm 10.10^{\mathrm{bc}}$ & $422.58 \pm 23.44^{\mathrm{c}}$ & $7.79 \pm 0.27^{\mathrm{e}}$ & $4.73 \pm 0.40^{\mathrm{fgh}}$ & $1.47 \pm 0.08^{\mathrm{e}}$ \\
\hline HFJR & $2.53 \pm 0.37^{\mathrm{h}}$ & $86.17 \pm 7.83^{\mathrm{f}}$ & $65.28 \pm 7.55^{\text {gh }}$ & $73.80 \pm 1.25^{\mathrm{c}}$ & $11.71 \pm 0.90^{\mathrm{e}}$ & $0.64 \pm 0.09^{\mathrm{c}}$ & $15.61 \pm 1.46^{\mathrm{efg}}$ & $216.17 \pm 9.81^{\mathrm{f}}$ & $8.47 \pm 0.11^{\mathrm{ab}}$ & $9.32 \pm 0.99^{\mathrm{a}}$ & $1.67 \pm 0.01^{\mathrm{abcd}}$ \\
\hline LS & $2.48 \pm 0.35^{\mathrm{h}}$ & $257.23 \pm 20.52^{\mathrm{de}}$ & $89.99 \pm 1.37^{\mathrm{efg}}$ & $13.63 \pm 3.06^{\mathrm{i}}$ & $5.26 \pm 0.67^{\mathrm{g}}$ & $1.38 \pm 0.51^{\mathrm{abc}}$ & $3.87 \pm 0.70^{\mathrm{h}}$ & $244.50 \pm 50.74^{\mathrm{f}}$ & $7.97 \pm 0.14^{\text {cde }}$ & $7.61 \pm 0.18^{\mathrm{b}}$ & $1.57 \pm 0.06^{\text {bcde }}$ \\
\hline
\end{tabular}

Note: XYWQ: Xiyuwangquan; HED: Hedong; GL: Guanlan; HL: Helu; ZY: Zhangyu; LL: Lilan; XXW: Xixiawang; BLLJ: Baolelijia; BGS: Bagesi; YH: Yuhuang; YM Yuma; XG: Xige; HD: Huida; HFJR: Hongfenjiarong; LS: Luoshan. SOC: soil organic carbon. TN: total nitrogen. TP: total phosphorus. TK: total potassium. aP: available phosphorus. aK: available potassium. Different lowercase letters indicate significant differences according to Duncan's multiple range test at the $p<0.05$ level. Results are reported as the mean $\pm \mathrm{SD}(n=3)$.

\subsection{Chemical variable analyses of grape berries and resulting wine}

The sugar content, titratable acidity and $\mathrm{pH}$ of grape and wine were determined according to Wang et al. methods ${ }^{[24]}$. The content of total phenols in wine was determined by the Folin-Ciocalteu method. The wine tannin content was measured by the Folin-Dennis method. The total anthocyanin content of resulting wine was determined by the $\mathrm{pH}$ differential method. The total flavonoids content was determined with $\mathrm{NaNO}_{2}-\mathrm{AlCl}_{3}{ }^{[25]}$. Flavan-3-ol content was analyzed by the method described by a previous protocol $^{[26]}$.

\subsection{Bacterial and fungal high-throughput sequencing and sequence processing}

Microbial DNA was extracted from $0.25 \mathrm{~g}$ soil using the OMEGA Soil DNA Kit (M5635-02) (Omega Bio-Tek, Norcross, GA, USA). The bacterial V3-V4 hypervariable 16S rRNA region and the fungal ITS1 region were amplified by polymerase chain reaction (PCR) using primers. The 338F (5'-ACTCCTACGGGA GGCAGCAG-3') and 806R (5'-GGACTACHVGGGTWTCTAAT$3^{\prime}$ ) primers were designed for $\mathrm{V} 3-\mathrm{V} 4$. The fungal IST1 region was amplified by primers ITS5F (5'-GGAAGTAAAAGTCGTAA CAAGG-3') and ITS1R (5'- GCTGCGTTCTTCATCGATGC-3'). The volumes of PCR amplification contained $5 \mu \mathrm{L}$ of buffer $(5 \mathrm{x})$, $0.25 \mu \mathrm{L}$ of Fast Pfu DNA Polymerase ( $5 \mathrm{U} / \mu \mathrm{L}), 2 \mu \mathrm{L}(2.5 \mathrm{mmol} / \mathrm{L})$ dNTPs, $1 \mu \mathrm{L}(10 \mu \mathrm{mol} / \mathrm{L})$ of each forward and reverse primer, $1 \mu \mathrm{L}$ of DNA template, and $14.75 \mu \mathrm{L} \mathrm{ddH}_{2} \mathrm{O}$. PCR amplification for both bacteria and fungi was performed as follows: $98^{\circ} \mathrm{C}$ for $5 \mathrm{~min}$; 30 cycles of $98^{\circ} \mathrm{C}$ for $30 \mathrm{~s}, 52^{\circ} \mathrm{C}$ and $55^{\circ} \mathrm{C}$ for $45 \mathrm{~s}$ (bacteria and fungi, respectively), $72^{\circ} \mathrm{C}$ for $45 \mathrm{~s}$; with a final extension at $72^{\circ} \mathrm{C}$ for $5 \mathrm{~min}$. Next, the PCR products were verified by $2 \%$ agarose gel electrophoresis. The PCR products were mixed in equal density ratios and then purified using a Qiagen Gel Extraction Kit (Qiagen, Germany). The purified amplicons were then sequenced on an Illumina NovaSeqPE250 platform by Shanghai Personal Biotechnology Co., Ltd. (Shanghai, China).
Sequences were filtered and chimaera-checked using Quantitative Insights Into Microbial Ecology (QIIME) ${ }^{[27]}$. After chimeric sequences were identified and removed to obtain effective tags, the remaining sequences were clustered by UCLUST and assigned to operational taxonomic units (OTUs) with 97\% similarity. The bacteria were identified using the Silva reference database (http://www.arb-silva.de) with the RDP classifier, and the fungi were identified using the Unite database (https://unite.ut.ee/) with the BLAST tool in QIIME (http://qiime.org/index.html). Community diversity indicators, including rarefaction curves, observed species, the Shannon-Wiener index, and the Chaol estimator were calculated for bacteria and fungi (the minimum number of sequences required to normalize the differences in sequencing depth) using QIIME.

\subsection{Multifunctionality analysis}

The ecosystem multifunctionality index includes three components: soil chemical functions (SCF), soil physical functions (SPF) and plant functions (PF). In the present study, we assessed thirteen ecosystem functions, including $\mathrm{SOC}, \mathrm{TN}, \mathrm{TP}, \mathrm{TK}, \mathrm{NO}_{3}{ }^{-} \mathrm{N}$, $\mathrm{NH}_{4}{ }^{+}-\mathrm{N}$, aP, aK, soil $\mathrm{pH}$, soil water content, soil bulk density, chlorophyll content, and vine pruning weight. $\mathrm{N}, \mathrm{P}$ and $\mathrm{K}$ contents in soil often restrict the primary production of terrestrial ecosystems. $\mathrm{NO}_{3}{ }^{-} \mathrm{N}$ and $\mathrm{NH}_{4}{ }^{+}-\mathrm{N}$ determinations provide two important mineral nitrogen sources. $\mathrm{aP}$ and aK evaluate the direct sources of $\mathrm{P}$ and $\mathrm{K}$ needed by vines. Chlorophyll is a good indicator of nutritional stress, photosynthetic capacity, and growth status of vines.

Several methods can be used to calculate the multifunctionality index, including single functions, turnover, averaging, and thresholds (including single thresholds and multiple thresholds) ${ }^{[28]}$. Each method has its own advantages and disadvantages. For example, the average approach is simple and intuitive, while one of the drawbacks of the turnover approach is that some functions may be affected by one or several species. The averaging and threshold approaches have been commonly used ${ }^{[29-31]}$. To allow 
for comparisons with other studies, averaging and multiple-threshold multifunctionality were calculated in this study. The averaging approach is to obtain a single index by standardizing and averaging the different functions ${ }^{[32]}$. Z-score transformation was carried out to standardize the data of soil microbial diversity and ecosystem functions ${ }^{[32]}$. The multiple-thresholds approach was carried out with a continuous gradient of thresholds, examining the slope of the fitted curve at different thresholds. The "multifunc" package ${ }^{[28]}$ in $\mathrm{R}$ software 3.6 was used to calculate multifunctionality indices.

\subsection{Statistical analyses}

One-way ANOVAs were conducted to assess the differences in soil properties, quality of grape berries and resulting wine, alpha diversity of soil bacterial and fungal communities, and ecosystem multifunctionality. Duncan's tests were used for multiple comparisons. Differences were considered significant at $p<0.05$. The Spearman method was used in R software 3.6 to determine the correlations of soil bacterial and fungal diversity with multiple ecosystem functions and the correlations of multiple ecosystem functions with wine quality. A principal coordinate analysis (PCoA) was performed to evaluate the differences in bacterial and fungal community structure among vineyards based on Bray-Curtis distances. A redundancy analysis (RDA) was conducted using $\mathrm{R}$ software to analyze the responses of multiple ecosystem functions to the wine quality from each vineyard. A heatmap was drawn with R software 3.6. Graphs were plotted using Origin 9.0.

\section{Results}

\subsection{Soil microbial community composition}

3.1.1 Alpha diversity of soil bacterial and fungal communities

The number of bacterial OTUs did not show significant differences among these vineyards (Table 2). The Chao1 index for bacterial communities showed a different pattern from that of the variation in bacterial OTUs and was highest at GL vineyard. The Shannon index, showing the diversity of microbial communities, was lower for the bacterial community at HFJR vineyard than the other vineyards. The Simpson index for the bacterial community also showed the lowest value at HFJR vineyard, as did the Shannon index. The number of OTUs, Chao1 estimator, and Shannon diversity of the fungal communities varied among the fifteen vineyards. The greatest number of fungal OTUs was at LS vineyard, greater than those at XYWQ, GL, HL, BGS, XG, HD, and HFJR vineyards. The fungal Chaol index showed a pattern that was similar to the trend of fungal OTUs and was affected by latitude, with the highest value at LS vineyard. The Shannon index of the fungal community did not show a significant difference among the vineyards in these main wine sub-regions, including Shizuishan, Yinchuan and Yuquanying.

Table 2 Alpha diversities of soil bacterial and fungal community of fifteen vineyards

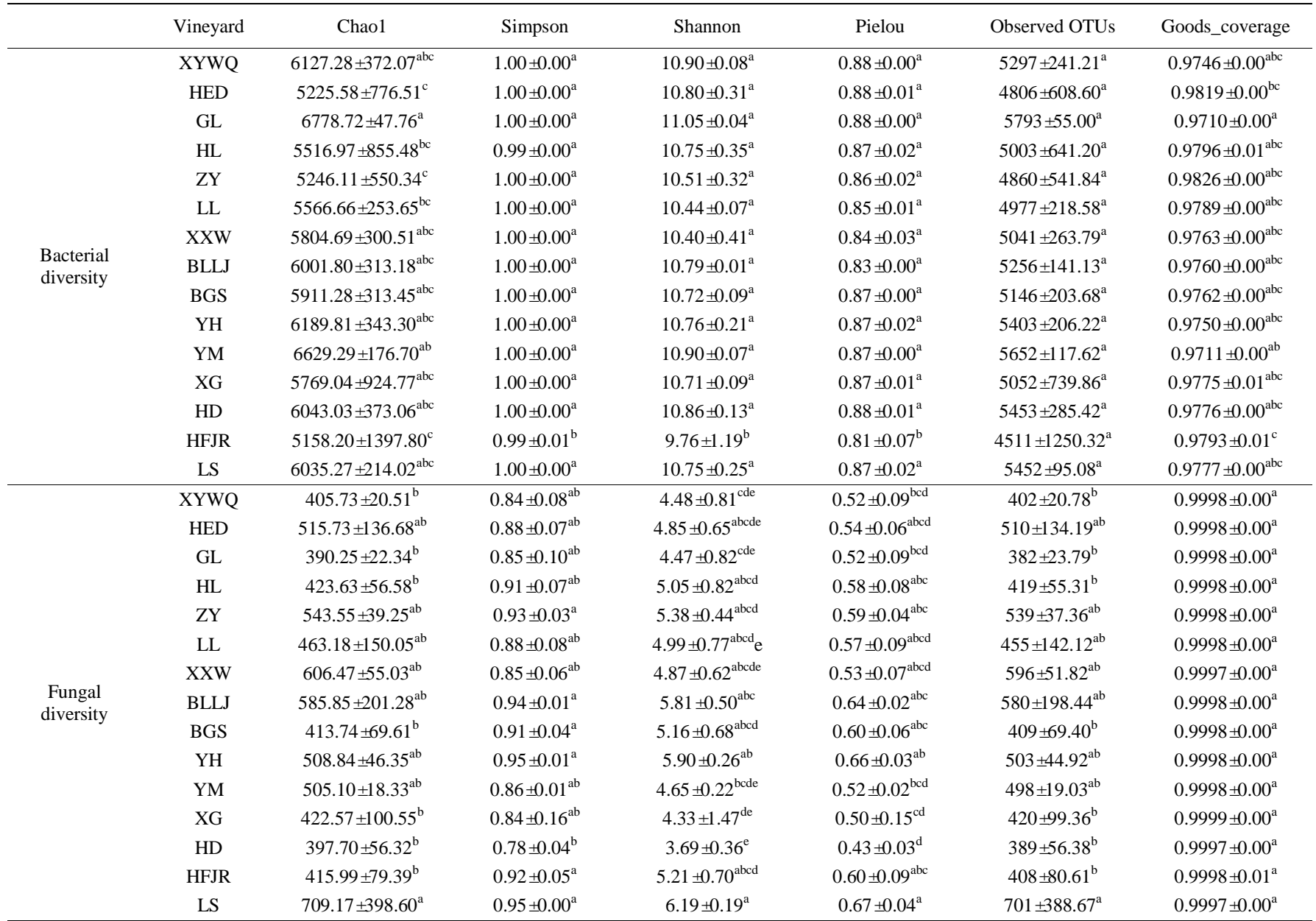

Note: XYWQ: Xiyuwangquan; HED: Hedong; GL: Guanlan; HL: Helu; ZY: Zhangyu; LL: Lilan; XXW: Xixiawang; BLLJ: Baolelijia; BGS: Bagesi; YH: Yuhuang; YM Yuma; XG: Xige; HD: Huida; HFJR: Hongfenjiarong; LS: Luoshan. Different lowercase letters indicate significant differences according to Duncan's multiple range test at the $p<0.05$ level. Results are reported as the mean $\pm \mathrm{SD}(n=3)$.

3.1.2 Soil bacterial and fungal community composition Actinobacteria was the most abundant bacterial phylum among these sites, accounting for $32.38 \%$ of all sequences on average, followed by Proteobacteria (30.62\%), Chloroflexi (11.66\%), 
Acidobacteria (8.12\%), and Gammaproteobacteria (5.81\%) (Figure 2a). The relative abundance of Actinobacteria was highest at XYWQ and GL vineyards. However, the relative abundance of Proteobacteria in vineyards from Qingtongxia and Hongsipu regions was higher than that at vineyards from Shizuishan and Yinchuan regions. PCoA based on Bray-Curtis distances was applied to visualize the overall patterns of bacterial and fungal community composition at each vineyard from these five wine sub-regions (Figure 3). For bacterial communities (Figure 3a), all vineyards tended to be separated, which indicated that bacterial community structure has differentiated among the vineyards.
Ascomycota was the dominant fungal phylum (82.98\%), followed by Mortierellomycota (7.72\%) and Basidiomycota (7.06\%) (Figure $2 b)$. The abundances of these three phyla significantly differed $(p<0.05)$ among vineyards from different locations. According to PCoA (Figure $3 b$ ), the fungal communities of some vineyards, such as $\mathrm{YH}$ and BLLJ, tended to be grouped together, which indicated that they shared similar bacterial community structure. Overall, the fungal community composition at different sites was not totally affected by vineyard location, indicating that fungal community composition was less affected than bacterial community composition.
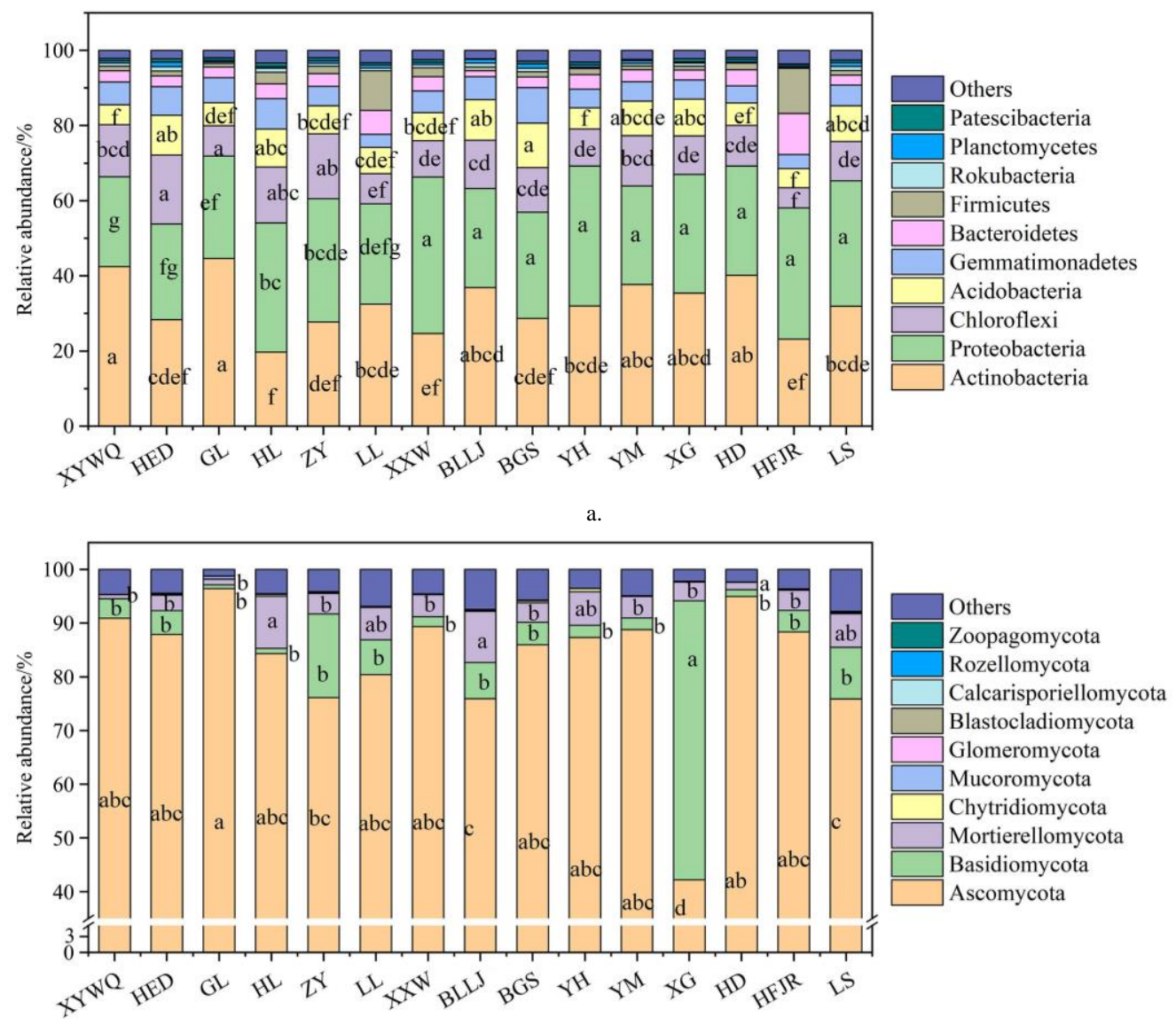

b.

Note: XYWQ: Xiyuwangquan; HED: Hedong; GL: Guanlan; HL: Helu; ZY: Zhangyu; LL: Lilan; XXW: Xixiawang; BLLJ: Baolelijia; BGS: Bagesi; YH: Yuhuang; YM: Yuma; XG: Xige; HD: Huida; HFJR: Hongfenjiarong; LS: Luoshan.

Figure 2 Relative abundance of soil bacterial (a) and fungal (b) community based on phylum level of grape vineyards

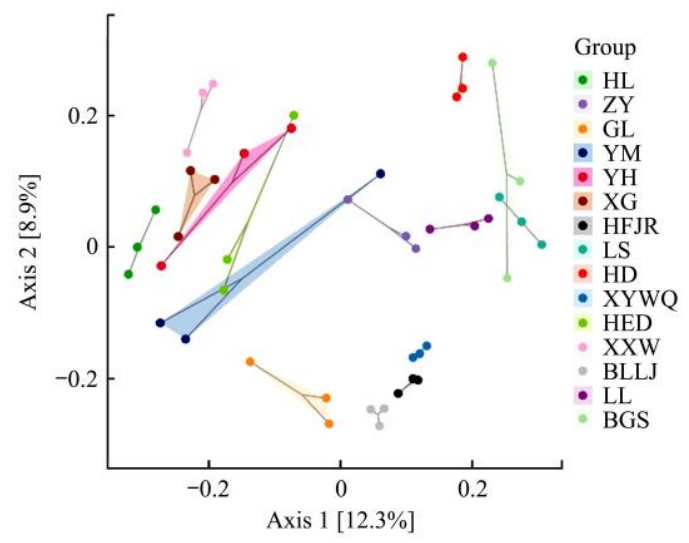

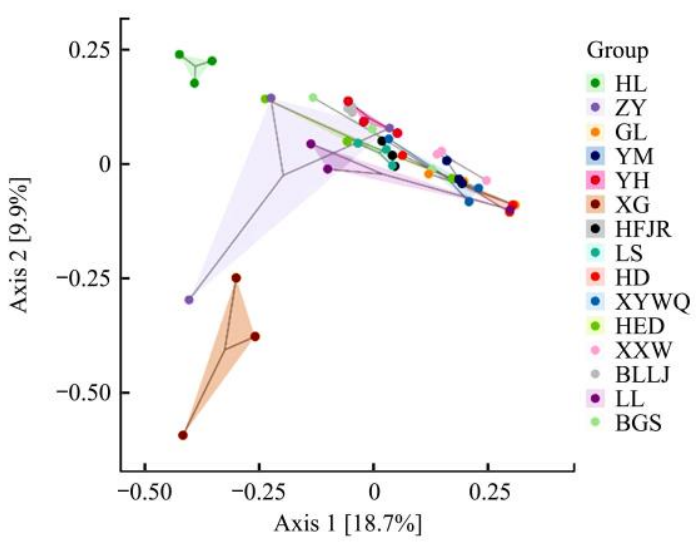

b.

Note: XYWQ: Xiyuwangquan; HED: Hedong; GL: Guanlan; HL: Helu; ZY: Zhangyu; LL: Lilan; XXW: Xixiawang; BLLJ: Baolelijia; BGS: Bagesi; YH: Yuhuang; YM: Yuma; XG: Xige; HD: Huida; HFJR: Hongfenjiarong; LS: Luoshan.

Figure 3 Principal coordinates analysis (PCoA) of microbial community composition based on soil bacterial (a) and fungal (b) relative abundance of OTUs 


\subsection{Ecosystem multifunctionality and its relationship with} microbial diversity

The ecosystem multifunctionality index calculated by the averaging method was highest at LS vineyard and lowest in HL vineyard (Figure 4a). Values at LL, XXW, BLLJ, and BGS vineyards from the same region were all positive. Overall, ecosystem multifunctionality did not show obvious differences among the vineyards. Soil chemical functions were also similar among the vineyards (Figure 5). Soil physical functions showed a similar pattern at vineyards from Shizuishan, Yinchuan, and Yuquanying regions but an opposite pattern at vineyards from Qingtongxia and Hongsipu regions (Figure 6).
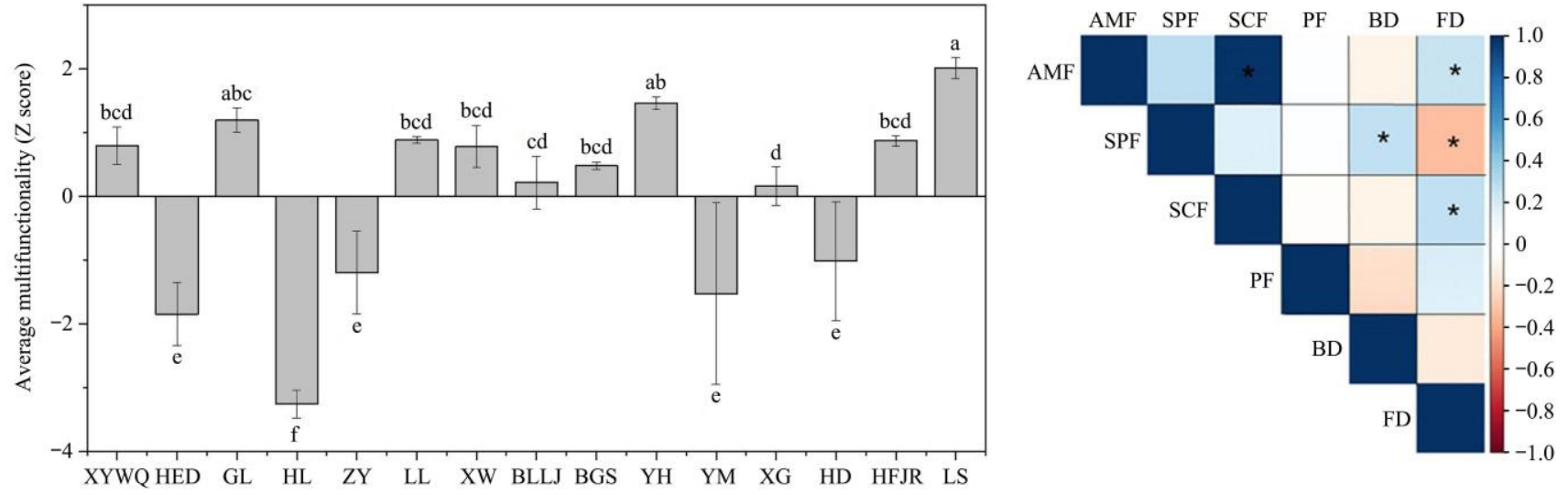

b.

Note: XYWQ, Xiyuwangquan; HED, Hedong; GL, Guanlan; HL, Helu; ZY, Zhangyu; LL, Lilan; XXW, Xixiawang; BLLJ, Baolelijia; BGS, Bagesi; YH, Yuhuang; YM, Yuma; XG, Xige; HD, Huida; HFJR, Hongfenjiarong; LS, Luoshan. In right panel: AMF, average multifunctionality; SPF, soil physical multifunctionality; SCF, soil chemical multifunctionality; $\mathrm{PF}$, plant multifunctionality; $\mathrm{BD}$, bacterial diversity; $\mathrm{FD}$, fungal diversity. $*$ indicated significant correlations ( $p<0.05$ ).

Figure 4 Average multifunctionality index of fifteen vineyards along the latitude gradients (a) and the relationship between average multifunctionality indices with microbial diversity (b)

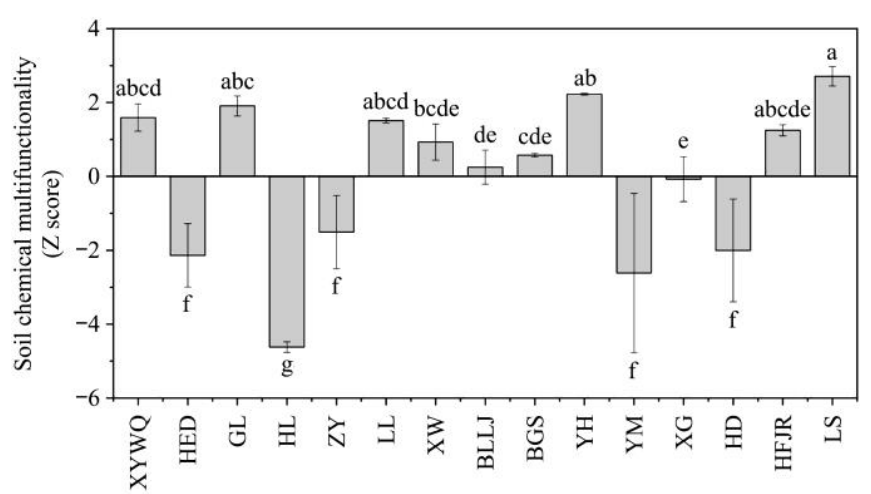

Note: XYWQ: Xiyuwangquan; HED: Hedong; GL: Guanlan; HL: Helu; ZY: Zhangyu; LL: Lilan; XXW: Xixiawang; BLLJ: Baolelijia; BGS: Bagesi; YH: Yuhuang; YM: Yuma; XG: Xige; HD: Huida; HFJR: Hongfenjiarong; LS: Luoshan.

Figure 5 Average multifunctionality index of soil chemical properties of fifteen vineyards along the latitude gradients

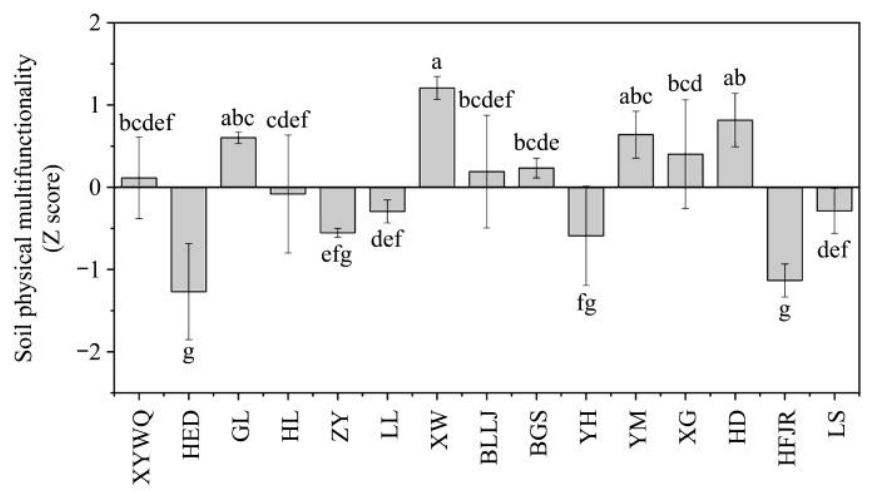

Note: XYWQ: Xiyuwangquan; HED: Hedong; GL: Guanlan; HL: Helu; ZY: Zhangyu; LL: Lilan; XXW: Xixiawang; BLLJ: Baolelijia; BGS: Bagesi; YH: Yuhuang; YM: Yuma; XG: Xige; HD: Huida; HFJR: Hongfenjiarong; LS: Luoshan.

Figure 6 Average multifunctionality index of soil physical properties of fifteen vineyards along the latitude gradients
Correlation analysis revealed that the bacterial diversity (BD) was not significantly correlated with average multifunctionality (AMF) but was significantly correlated with SPF (Figure 4b). Fungal diversity (FD) was significantly positively correlated with the AMF of ecosystems and SCF and negatively correlated with SPF. According to the multiple-threshold method (Figure 7), $T_{\text {min }}$, the minimum threshold when diversity influences multifunctionality, was $23 \%$ for the bacterial community and $9 \%$ for the fungal community. $T_{\max }$, the maximum threshold when diversity has no effect on multifunctionality, was $41 \%$ for the bacterial community and $34 \%$ for the fungal community. Under the condition of a threshold below $75 \%$, the slope of ecosystem multifunctionality and diversity was positive for the bacterial community, indicating that ecosystem multifunctionality was maintained by bacterial diversity. Under the condition of a threshold exceeding $75 \%$, the slope of the relationship between ecosystem multifunctionality and fungal community diversity was positive, revealing that ecosystem multifunctionality was maintained by fungal diversity.

\subsection{Quality of grape berries and the resulting wine}

3.3.1 Quality of grape berries

From the results of grape quality analysis (Table 3), the total sugar content of grape berries was close to or greater than $200 \mathrm{~g} / \mathrm{L}$, indicating that the grapes of each vineyard ripened well in this study. The total sugar content of grapes was higher at YM vineyard than at the other sites, while the titratable acidity content was higher at $\mathrm{YH}, \mathrm{HD}$, and LS vineyards than at the other vineyards. The $\mathrm{pH}$ of grape berries showed a pattern different from those for total sugar and titratable acidity, with the highest value at BGS vineyard.

\subsubsection{Wine quality}

As presented in Table 4, the alcohol content of wine ranged from $12.86 \%$ to $16.03 \%(\mathrm{v} / \mathrm{v})$, with the highest value at $\mathrm{YH}$ vineyard. Vineyards from the Yinchuan region exhibited the highest values for total extract, residual sugar, total tannins, total 
flavonoids, total phenolics and titratable acidity of wine. Moreover, the total tannin content, total anthocyanin content, total phenolics content, and titratable acidity were all highest at GL vineyard, with $717.64 \mathrm{mg} / \mathrm{L}, 4688.51 \mathrm{mg} / \mathrm{L}, 702 \mathrm{mg} / \mathrm{L}$, and $7.53 \mathrm{~g} / \mathrm{L}$, respectively. Interestingly, the lowest values for total extract, residual sugar, total flavonoids, and phenolics content were

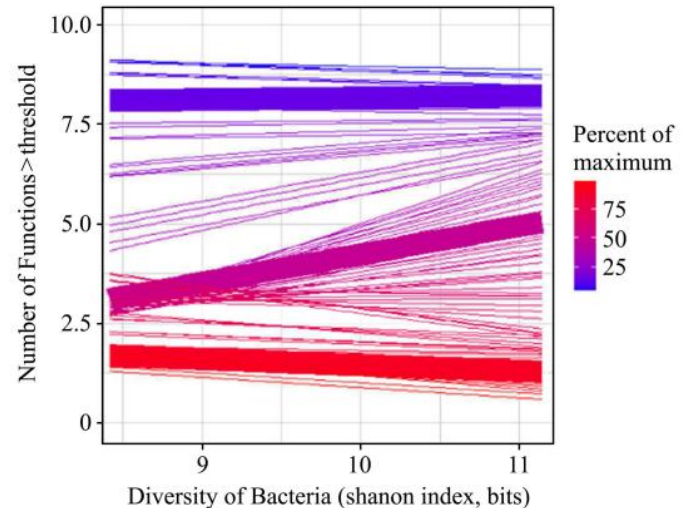

a.

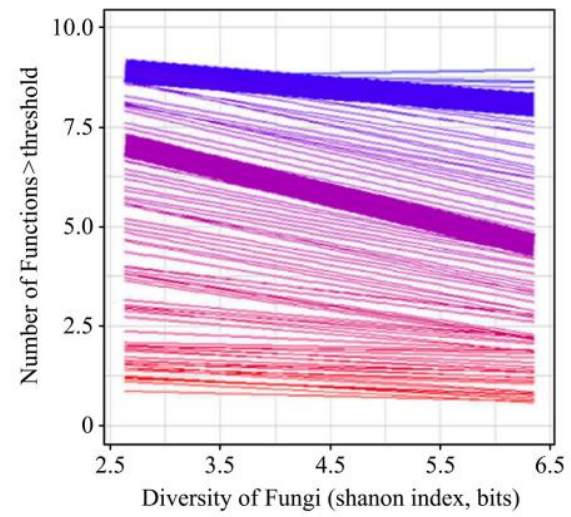

all at sites in the Hongsipu region. The residual sugar content ranged between $0.93 \mathrm{~g} / \mathrm{L}$ at $\mathrm{HD}$ vineyard and $2.43 \mathrm{~g} / \mathrm{L}$ at $\mathrm{HL}$ vineyard. The total flavan-3-ol content ranged between $290.17 \mathrm{mg} / \mathrm{L}$ at LL vineyard and $944.45 \mathrm{mg} / \mathrm{L}$ at $\mathrm{HD}$ vineyard. The titratable acidity ranged from $5.23 \mathrm{~g} / \mathrm{L}$ at $\mathrm{HL}$ vineyard to $7.53 \mathrm{~g} / \mathrm{L}$ at GL vineyard.

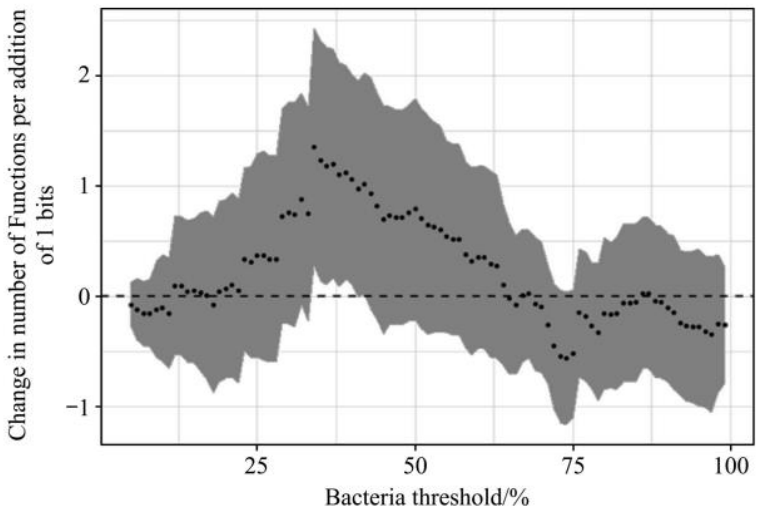

b.

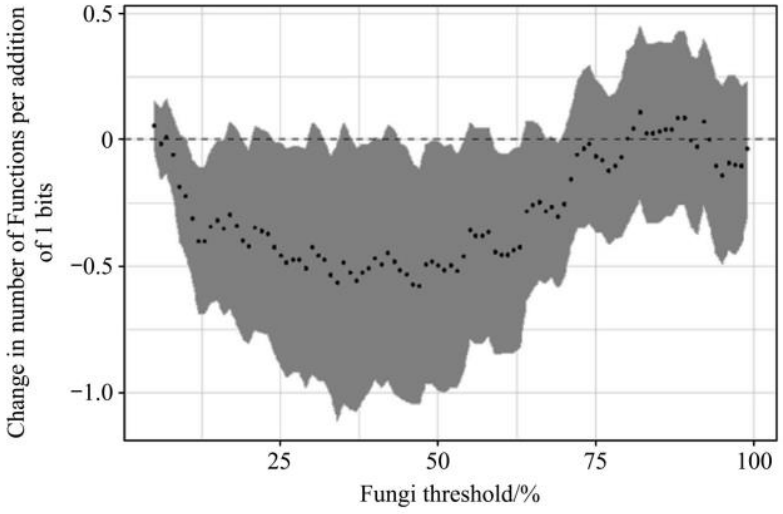

d.

Figure 7 Relationships between diversity of bacteria $(a, b)$ and fungi $(c, d)$ and the number of functions beyond a threshold of maximum observed value

Table 3 Physiochemical property of grape berries of fifteen vineyards

\begin{tabular}{|c|c|c|c|c|c|c|c|}
\hline Vineyard & Titratable acidity $/ g \cdot \mathrm{L}^{-1}$ & Total sugar/g. $\mathrm{L}^{-1}$ & $\mathrm{pH}$ & Vineyard & Titratable acidity/g. $\mathrm{L}^{-1}$ & Total sugar/g. $\mathrm{L}^{-1}$ & $\mathrm{pH}$ \\
\hline XYWQ & $4.48 \pm 0.04^{\mathrm{d}}$ & $242.17 \pm 5.97^{b}$ & $3.95 \pm 0.01^{\mathrm{cd}}$ & BGS & $4.09 \pm 0 .^{11 \mathrm{~g}}$ & $226.33 \pm 15.12^{\mathrm{bc}}$ & $4.10 \pm 0.02^{\mathrm{a}}$ \\
\hline HED & $4.76 \pm 0.04^{c}$ & $207.33 \pm 17.56^{\mathrm{def}}$ & $3.77 \pm 0.00^{\mathrm{f}}$ & YH & $6.41 \pm 0.04^{\mathrm{a}}$ & $203.33 \pm 7.94^{\mathrm{ef}}$ & $3.61 \pm 0.01^{\mathrm{i}}$ \\
\hline GL & $4.73 \pm 0.03^{\mathrm{c}}$ & $219.17 \pm 4.51^{\mathrm{cde}}$ & $3.72 \pm 0.01^{\mathrm{g}}$ & YM & $4.28 \pm 0.11^{\mathrm{ef}}$ & $258.66 \pm 4.01^{\mathrm{a}}$ & $4.03 \pm 0.02^{\mathrm{b}}$ \\
\hline HL & $5.00 \pm 0.06^{\mathrm{b}}$ & $197.00 \pm 9.73^{\mathrm{f}}$ & $3.92 \pm 0.01^{\mathrm{d}}$ & $\mathrm{XG}$ & $4.21 \pm 0.11^{\mathrm{fg}}$ & $230.83 \pm 11.84^{\mathrm{bc}}$ & $3.97 \pm 0.04^{\mathrm{c}}$ \\
\hline $\mathrm{ZY}$ & $4.82 \pm 0.18^{\mathrm{bc}}$ & $179.67 \pm 5.53^{\mathrm{g}}$ & $3.83 \pm 0.01^{\mathrm{e}}$ & HD & $6.24 \pm 0.04^{\mathrm{a}}$ & $215.67 \pm 2.47^{\text {cde }}$ & $3.59 \pm 0.00^{\mathrm{j}}$ \\
\hline XXW & $4.42 \pm 0.14^{\mathrm{de}}$ & $223.67 \pm 2.08^{\mathrm{cd}}$ & $3.70 \pm 0.02^{\mathrm{gh}}$ & LS & $4.48 \pm 0.04^{\mathrm{a}}$ & $242.17 \pm 5.97^{\mathrm{bc}}$ & $3.95 \pm 0.01^{\mathrm{h}}$ \\
\hline BLLJ & $4.18 \pm 0.05^{\mathrm{fg}}$ & $226.67 \pm 1.76^{\mathrm{bc}}$ & $3.70 \pm 0.02^{\mathrm{gh}}$ & & & & \\
\hline
\end{tabular}

Note: XYWQ: Xiyuwangquan; HED: Hedong; GL: Guanlan; HL: Helu; ZY: Zhangyu; LL: Lilan; XXW: Xixiawang; BLLJ: Baolelijia; BGS: Bagesi; YH: Yuhuang; YM: Yuma; XG: Xige; HD: Huida; HFJR: Hongfenjiarong; LS: Luoshan. Different lowercase letters indicate significant differences according to Duncan's multiple range test at the $p<0.05$ level. Results are reported as the mean $\pm \operatorname{SD}(n=3)$.

Table 4 Oenological parameters of wine of fifteen vineyards

\begin{tabular}{|c|c|c|c|c|c|c|c|c|c|c|}
\hline Vine & $1 \%$ & $/ \mathrm{g}$. & -1 & 1 & $/ \mathrm{n}$ & $\begin{array}{l}\text { yanins } \\
\text { y }\end{array}$ & $/ \mathrm{n}$ & olics & & $\mathrm{pH}$ \\
\hline X & & & & & (3) & & & & & \\
\hline $\mathrm{H}$ & $14.34 \pm 2.18^{\mathrm{b}}$ & $2.50 \pm 0.17^{\mathrm{c}}$ & $78 \pm 0.01^{\mathrm{b}}$ & $42.21 \pm 24.96^{\mathrm{f}}$ & $13.54 \pm 34.71^{\text {gh }}$ & $24.39 \pm 12.20^{\mathrm{a}}$ & $898.44 \pm 111.40^{\mathrm{h}}$ & $464.60 \pm 37.68^{\mathrm{g}}$ & $20+006$ & $3.72 \pm 0.02$ \\
\hline GL & $14.18 \pm 0.06^{\mathrm{bc}}$ & $3.00 \pm 0.00^{\mathrm{a}}$ & $1.59 \pm 0.04^{\mathrm{d}}$ & $50.66 \pm 12.04^{b c}$ & $17.64 \pm 13.89^{\mathrm{a}}$ & & & $702.98 \pm 35.80^{\mathrm{a}}$ & $7.53 \pm 0.01^{\mathrm{a}}$ & $3.20 \pm 0.02^{\mathrm{e}}$ \\
\hline HL & & & & & $621.86 \pm 40.99^{\mathrm{bcd}}$ & & & & & \\
\hline $\mathrm{ZY}$ & $12.86 \pm 0.05^{\mathrm{h}}$ & $32.10 \pm 0.17^{\mathrm{cd}}$ & $1.00 \pm 0.02 \mathrm{i}$ & $723.11 \pm 36.41^{\mathrm{e}}$ & $429.39 \pm 23.54^{\mathrm{f}}$ & $225.21 \pm 26.53^{\mathrm{de}}$ & & $533.58 \pm 19.74 \mathrm{~d}^{\mathrm{ef}}$ & $5.65 \pm 0.06^{\mathrm{g}}$ & $3.71 \pm 5.44^{\mathrm{bc}}$ \\
\hline LL & $13.95 \pm 0.05^{\mathrm{d}}$ & $31.27 \pm 0.25^{\mathrm{f}}$ & $1.07 \pm 0.04^{\mathrm{h}}$ & $290.17 \pm 34.50^{\mathrm{i}}$ & $457.13 \pm 13.15^{\mathrm{f}}$ & $235.37 \pm 13.21^{\text {cde }}$ & $2591.99 \pm 21.22^{\mathrm{i}}$ & $433.47 \pm 5.59^{\mathrm{gh}}$ & $5.97 \pm 0.00^{\mathrm{e}}$ & $3.37 \pm 0.01^{\mathrm{de}}$ \\
\hline$X \times w$ & $12.97 \pm 0.05^{\mathrm{h}}$ & $29.90 \pm 0.17^{\mathrm{h}}$ & $1.17 \pm 0.03^{\mathrm{g}}$ & $563.96 \pm 77.44^{\mathrm{g}}$ & $427.78 \pm 32.43^{\mathrm{f}}$ & & $3553.64 \pm 82.28^{\mathrm{e}}$ & & $5.71 \pm 0.09^{\mathrm{fg}}$ & $3.54 \pm 0.01^{\mathrm{t}}$ \\
\hline
\end{tabular}




\begin{tabular}{|c|c|c|c|c|c|c|c|c|c|c|}
\hline Vineyard & $\begin{array}{l}\text { Alcoholicity } \\
1 \%, \mathrm{v} / \mathrm{v}\end{array}$ & $\begin{array}{c}\text { Total extract } \\
/ \mathrm{g} \cdot \mathrm{L}^{-1}\end{array}$ & $\mathrm{RS} / \mathrm{g} \cdot \mathrm{L}^{-1}$ & $\begin{array}{l}\text { Total flavan-3-ol } \\
\qquad / \mathrm{mg} \cdot \mathrm{L}^{-1}\end{array}$ & $\begin{array}{l}\text { Total tannin } \\
/ \mathrm{mg} \cdot \mathrm{L}^{-1}\end{array}$ & $\begin{array}{l}\text { Total anthocyanins } \\
\qquad / \mathrm{mg} \cdot \mathrm{L}^{-1}\end{array}$ & $\begin{array}{l}\text { Total flavonoids } \\
\qquad / \mathrm{mg} \cdot \mathrm{L}^{-1}\end{array}$ & $\begin{array}{l}\text { Total phenolics } \\
\quad / \mathrm{mg} \cdot \mathrm{L}^{-1}\end{array}$ & $\mathrm{TA} / \mathrm{g} \cdot \mathrm{L}^{-1}$ & $\mathrm{pH}$ \\
\hline BLLJ & $12.89 \pm 0.10^{\mathrm{h}}$ & $29.33 \pm 0.12^{\mathrm{i}}$ & $1.45 \pm 0.05^{\mathrm{e}}$ & $788.48 \pm 26.19^{\mathrm{d}}$ & $659.58 \pm 18.51^{\mathrm{b}}$ & $226.89 \pm 14.72^{\mathrm{de}}$ & $3948.71 \pm 22.18^{d}$ & $573.24 \pm 11.69^{c}$ & $5.95 \pm 0.05^{\mathrm{e}}$ & $4.09 \pm 0.58^{\mathrm{a}}$ \\
\hline YH & $16.03 \pm 0.10^{\mathrm{a}}$ & $33.33 \pm 0.25^{\mathrm{b}}$ & $1.72 \pm 0.04^{\mathrm{bc}}$ & $893.89 \pm 56.11^{\mathrm{ab}}$ & $644.70 \pm 41.66^{\mathrm{bc}}$ & $214.10 \pm 9.70^{\mathrm{ef}}$ & $4304.65 \pm 128.82^{\mathrm{bc}}$ & $643.87 \pm 16.30^{\mathrm{b}}$ & $6.46 \pm 0.07^{\mathrm{b}}$ & $3.48 \pm 0.01^{\text {cde }}$ \\
\hline YM & $14.13 \pm 0.27^{\mathrm{cd}}$ & $28.40 \pm 0.30^{\mathrm{j}}$ & $1.26 \pm 0.02^{\mathrm{f}}$ & $699.99 \pm 24.64^{\mathrm{e}}$ & $521.91 \pm 36.04^{\mathrm{e}}$ & $195.03 \pm 11.47^{\mathrm{fg}}$ & $3020.45 \pm 122.94^{\text {gh }}$ & $511.39 \pm 13.55^{\mathrm{f}}$ & $6.15 \pm 0.05^{\mathrm{d}}$ & $3.41 \pm 0.01^{\mathrm{de}}$ \\
\hline$X G$ & $13.47 \pm 0.10^{\mathrm{fg}}$ & $31.37 \pm 0.12 \mathrm{e}^{\mathrm{f}}$ & $1.26 \pm 0.04^{\mathrm{f}}$ & $828.42 \pm 16.66^{\mathrm{cd}}$ & $516.74 \pm 15.22^{\mathrm{e}}$ & $235.42 \pm 10.60^{\text {cde }}$ & $3941.52 \pm 380.02^{\mathrm{d}}$ & $556.18 \pm 10.46^{\text {cde }}$ & $6.32 \pm 0.06^{\mathrm{c}}$ & $3.35 \pm 0.01^{\mathrm{de}}$ \\
\hline HD & $13.03 \pm 0.18^{\mathrm{h}}$ & $26.63 \pm 0.29^{k}$ & $0.93 \pm 0.01^{\mathrm{j}}$ & $537.00 \pm 6.20^{\mathrm{gh}}$ & $351.21 \pm 16.98^{\mathrm{g}}$ & $191.88 \pm 7.29^{\mathrm{fg}}$ & $2411.58 \pm 22.84^{\mathrm{i}}$ & $391.48 \pm 6.66^{\mathrm{i}}$ & $5.76 \pm 0.05^{\mathrm{f}}$ & $3.56 \pm 0.01^{\mathrm{bcd}}$ \\
\hline HFJR & $14.12 \pm 0.05^{\mathrm{cd}}$ & $31.77 \pm 0.25^{\mathrm{de}}$ & $1.07 \pm 0.07^{\mathrm{h}}$ & $944.45 \pm 35.52^{\mathrm{a}}$ & $573.25 \pm 25.67^{\mathrm{d}}$ & $230.93 \pm 20.62^{\mathrm{de}}$ & $4274.15 \pm 150.84^{\mathrm{c}}$ & $644.76 \pm 11.19^{\mathrm{b}}$ & $6.15 \pm 0.08^{\mathrm{d}}$ & $3.46 \pm 0.01^{\mathrm{cde}}$ \\
\hline LS & $13.60 \pm 0.06^{\mathrm{ef}}$ & $30.47 \pm 0.25^{\mathrm{g}}$ & $1.10 \pm 0.05^{\mathrm{h}}$ & $855.34 \pm 31.42^{\mathrm{bc}}$ & $601.05 \pm 40.34^{\mathrm{cd}}$ & $260.56 \pm 22.40^{\mathrm{bc}}$ & $4215.74 \pm 97.39^{c}$ & $668.59 \pm 9.35^{\mathrm{b}}$ & $6.21 \pm 0.07^{\mathrm{d}}$ & $3.60 \pm 0.02^{\mathrm{bcd}}$ \\
\hline
\end{tabular}

Note: XYWQ: Xiyuwangquan; HED: Hedong; GL: Guanlan; HL: Helu; ZY: Zhangyu; LL: Lilan; XXW: Xixiawang; BLLJ: Baolelijia; BGS: Bagesi; YH: Yuhuang; YM Yuma; XG: Xige; HD: Huida; HFJR: Hongfenjiarong; LS: Luoshan. RS: Residual sugar. TA: Titratable acidity. Different lowercase letters indicate significant differences according to Duncan's multiple range test at the $p<0.05$ level. Results are reported as the mean $\pm \operatorname{SD}(n=3)$.

\subsection{Relationships between wine quality and multifunctionality}

As shown in Figure 8, AMF and SCF showed significant positive correlations with acidity of wine, while AMF and SCF displayed significant negative correlations with wine $\mathrm{pH}$. AMF, $\mathrm{PF}$, and SCF all had significant negative correlations with residual sugar content. The results of the multiple threshold approach are shown in Figure 7. In addition, PF was significantly negatively correlated with extract content. SPF exhibited significant negative correlations with alcohol and total anthocyanin content of the resulting wine.

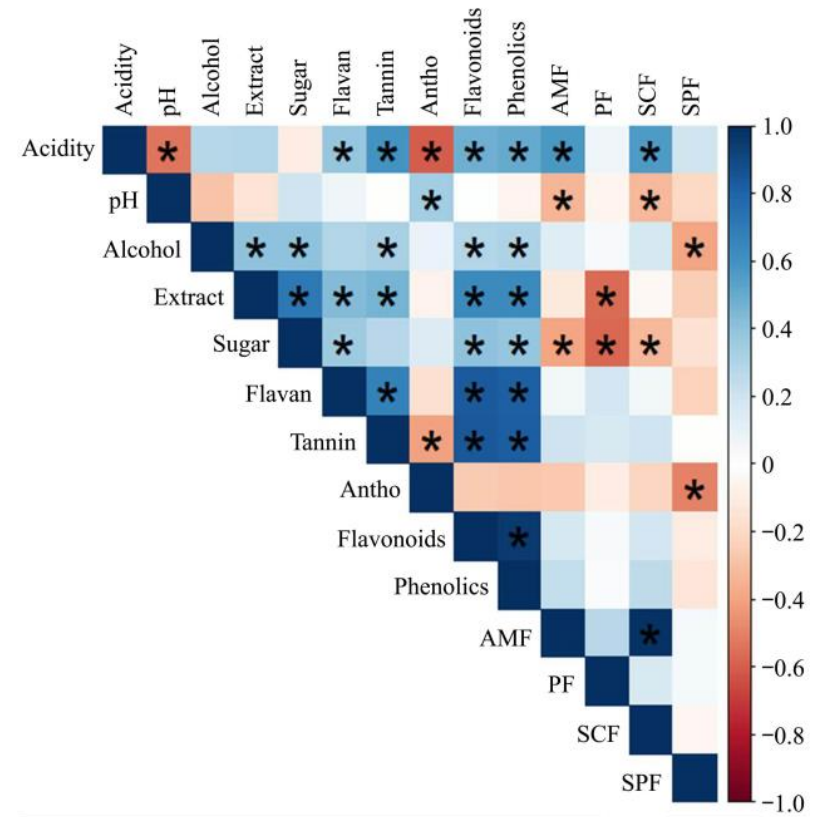

Note: Acidity represents titratable acidity; Alcohol represents alcoholicity; Extract represents total extract content; Flavan represents total flavan-3-ols content; Tannin represents total tannin content; Antho represents total anthocyanin content; Flavonoids represents total flavonoids content; Phenolics represents total phenolic content; AMF: average multifunctionality; SCF: soil chemical multifunctionality; SPF: soil physical multifunctionality; PF: plant multifunctionality. * indicated significant correlations $(p<0.05)$.

Figure 8 Heatmap of correlation between wine quality and multifunctionality ( $\mathrm{Z}$ score)

The RDA ordination plot showed the relationships between wine quality and aspects of ecosystem multifunctionality, including AMF, SCF, PF, and SPF (Figure 9). The first and second axes explained $11.08 \%$ and $4.76 \%$ of the variation, respectively. Overall, these ecosystem functions explained wine quality $(p<0.05)$. These multifunctionalities all significantly affected wine quality $(p<0.05)$. Similar to the results of correlation analysis, AMF and SCF exhibited significant positive correlations with the acidity of wine.

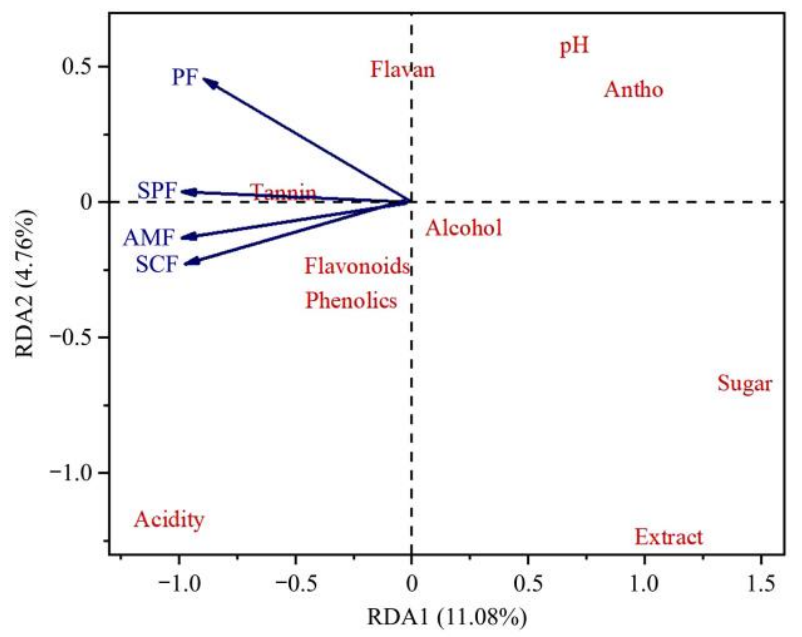

Note: Alcohol represents alcoholicity; Acidity represents titratable acidity; Extract represents total extract content; Flavan represents total flavan-3-ols content; Tannin represents total tannin content; Antho represents total anthocyanin content; Flavonoids represents total flavonoids content; Phenolics represents total phenolic content; AMF: average multifunctionality; SCF: soil chemical multifunctionality; SPF: soil physical multifunctionality; PF: plant multifunctionality.

Figure 9 Redundancy analysis of wine quality and ecosystem multifunctionality

\section{Discussion}

\subsection{Soil microbial community structure of vineyard}

The profiles of both bacterial and fungal communities showed significant differences among vineyards (Figures 2, 3, and Table 2). The bacterial community structure was different among the fifteen vineyards, while the differences in the fungal community structure were not as obvious (Figure 2). In addition, the Shannon diversity of the bacterial and fungal communities showed different patterns. The lowest bacterial diversity was at HFJR vineyard, and there was no significant difference in the Shannon diversity of the bacterial community among the other vineyards. However, fungal Shannon diversity varied more significantly. These results were consistent with findings from previous work conducted at vineyards in Xinjiang showing that the Shannon diversity of fungal communities showed greater variation than that of bacterial communities $^{[33]}$. Microbial community structure is affected by soil, climate, plant type and diversity, and other factors. The ecogeographical conditions for suitable wine grape-planting areas are complex and diverse. Moreover, Actinobacteria and Proteobacteria were the dominant bacterial phyla in each vineyard, which was consistent with Wei et al. ${ }^{[34]}$. Microbial taxa with different strategies for nutrient acquisition, such as copiotrophic and oligotrophic groups, are impacted by soil conditions. The 
oligotrophic hypothesis states that nutrient-rich conditions are beneficial for copiotrophic but not oligotrophic bacterial growth ${ }^{[35]}$. In the present study, the relative abundance of Acidobacteria, considered an oligotrophic group, was much higher than the relative abundance of Firmicutes, which is classified as a copiotrophic group. This is consistent with the poor quality of soil in northwest China. Ascomycota was the main fungal phylum in each vineyard, followed by Basidiomycota and Mortierellomycota. Basidiomycetes are typically saprotrophic and very sensitive to organic matter decomposition, especially plant litter with high lignin content ${ }^{[36,37]}$. There was very little plant litter in the human-modified ecosystems under study, leading to a relatively lower abundance of Basidiomycota. The soil microbial community composition and structure were affected by climate, soil fertility and other factors in different wine grape-producing areas of Xinjiang, which was supported by the results of several previous studies ${ }^{[38,39]}$.

\subsection{Drivers of ecosystem multifunctionality}

The changing patterns of ecosystem multifunctionality and soil functions of each vineyard and their relationships with bacterial and fungal diversity were explored. In the current study, as these approaches have their own advantages and disadvantages ${ }^{[28]}$, two metrics, averaging and multiple thresholds, were selected to calculate multifunctionality indices. With the method of averaging, the multiple ecosystem functions differed significantly among the experimental vineyards, illustrating an imbalance in the tradeoffs among single functions of these vineyards ${ }^{[40]}$. This was because vineyards from different locations varied in soil biological traits, soil physical traits, and soil nutrient contents, resulting in differences in vine properties. More importantly, only the vineyards from Yuquanying exhibited overall positive values, and the ecosystem multifunctionality of vineyards from different wine sub-regions showed different patterns, which reflects that the ecosystem multifunctionality of vineyards may depend more on specific environmental factors at a fine scale, especially the microclimatic and soil conditions in the vineyard.

Some previous studies have illustrated that microbial diversity promotes ecosystem multifunctionality in the natural environment $^{[10,13,41]}$, which also indicated that variations in bacterial and fungal diversity could further influence multifunctionality. Ecosystems with single plant types, such as farming systems or economic forest systems, have lower biodiversity than less disturbed or natural terrestrial ecosystems ${ }^{[42]}$. Jing et al. ${ }^{[10]}$ found that the organic fertilizer application increased soil multifunctionality by positively promoting both bacterial and fungal diversity. In this study, fungal diversity rather than bacterial diversity showed a positive relationship with ecosystem multifunctionality in the vineyard. Consequently, any alternations in fungal diversity resulting from field management practices $^{[11,43,44]}$, such as pesticide application, fertilization, and residue management, may affect multifunctionality by shifting fungal diversity. Furthermore, positive correlations between soil bacterial diversity and some single functions, such as SPF, were found (Figure 4). However, bacterial diversity could not maintain ecosystem multifunctionality. These results indicate that the effect of bacterial diversity may not be strong enough to influence overall multifunctionality in the experimental vineyards. Fungal diversity showed a significant positive relationship with SCF and a negative relationship with SPF.

4.3 Response of wine quality to ecosystem multifunctionality In the current study, ecosystem multifunctionality was found to have different relationships with various indices of wine quality, such as being positively correlated with titratable acidity and negatively correlated with $\mathrm{pH}$ and residual sugar content of wine. In addition, indices of wine quality showed different responses to different functions. For example, acidity responded positively, and $\mathrm{pH}$ and residual sugar content of wine responded negatively to SCF, while both the alcohol and total anthocyanin content of wine responded negatively to SPF. This was because the soil water content included in SPF was negatively correlated with the total anthocyanin content of wine ${ }^{[45]}$. It was reported that wine acidity was positively affected by soil $\mathrm{pH}$ and soil water content but negatively affected by soil organic matter content. In this study, wine acidity was positively correlated with SCF, including soil organic carbon content and $\mathrm{pH}$, showing the tradeoffs among these factors affecting acidity. Furthermore, the phenolics content of wine has been reported to be affected by the soil $\mathrm{N}$ content and positively affected by the $\mathrm{K}$ content ${ }^{[46]}$; thus, there was no significant relationship between multifunctionality and the phenolics content in this study.

\section{Conclusions}

This study shows that microbial community structure, ecosystem multifunctionality, and wine quality varied among the experimental vineyards, showing different trends in different wine sub-regions affected by different specific factors at a fine scale. Moreover, our findings provide experimental evidence that is consistent with previous results showing that fungal diversity promotes the multifunctionality of vineyards. However, bacterial diversity was not able to explain ecosystem multifunctionality as was fungal diversity. Moreover, different multifunctionality indices promote different aspects of wine quality, showing the effects of tradeoffs among functions on wine quality. The results reveal relevant ecological relationships between biodiversity and ecosystem functions in vineyards. In addition, it is suggested that management practices that are beneficial for fungal diversity should be selected to maintain ecosystem functions in vineyards.

\section{Acknowledgements}

This work was financially supported by the National Key Research and Development of China (2017YFC1502806), Key Research and Development of Ningxia Hui Autonomous Region (2021BEF02017), Key Research and Development of Shaanxi province (2020ZDLNY07-08), Key Research and Development of Sichuan province (2020YFN0149), Fundamental Research Funds for the Central Universities (2452017148), Shaanxi Agricultural Collaborative Innovation and Extension Alliance (LMZD202105), and Scientific and Technological Innovation of Experimental Demonstration Station of Northwest A\&F University (SFZ202105).

\section{[References]}

[1] Brandt P, Abson D J, DellaSala D A, Feller R, von Wehrden H Multifunctionality and biodiversity: ecosystem services in temperate rainforests of the Pacific Northwest, USA. Biological Conservation, 2014 169: $362-371$.

[2] van der Plas F, Manning P, Soliveres S, Allan E, Scherer-Lorenzen M Verheyen $\mathrm{K}$, et al. Biotic homogenization can decrease landscape-scale forest multifunctionality. Proceedings of the National Academy of Sciences of the United States of America, 2016; 113(13): 3557-3562.

[3] Delgado-Baquerizo M, Trivedi P, Trivedi C, Eldridge D J, Reich P B, Jeffries $\mathrm{T} \mathrm{C}$, et al. Microbial richness and composition independently drive soil multifunctionality. Functional Ecology, 2017; 31(12): 2330-2343. 
[4] Sharafatmandrad M, Mashizi A K. Investigating distribution of ecosystem services in rangeland landscapes: an approach based on weighted key functional traits. Ecological Indicators, 2020; 111: 105971. doi: 10.1016/j.ecolind.2019.105971.

[5] Birkhofer K, Andersson G K S, Bengtsson J, Bommarco R, Dänhardt J, Ekbom B, et al. Relationships between multiple biodiversity components and ecosystem services along a landscape complexity gradient. Biological Conservation, 2018; 218: 247-253.

[6] Schuldt A, Assmann T, Brezzi M, Buscot F, Eichenberg D, Gutknecht J, et al. Biodiversity across trophic levels drives multifunctionality in highly diverse forests. Nature Communications, 2018; 9: 2989. doi: 10.1038/ s41467-018-05421-z.

[7] Wang L, Delgado-Baquerizo M, Wang D, Isbell F, Liu J, Feng C, et al. Diversifying livestock promotes multidiversity and multifunctionality in managed grasslands. Proceedings of the National Academy of Sciences of the United States of America, 2019; 116: 6187-6192.

[8] Griggs R G, Steenwerth K L, Mills D A, Cantu D, Bokulich N A. Sources and assembly of microbial communities in vineyards as a functional component of winegrowing. Frontiers in Microbiology, 2021; 12: 673810. doi: 10.3389/fmicb.2021.673810.

[9] Isbell F, Calcagno V, Hector A, Connolly J, Harpole W S, Reich P B, et al. High plant diversity is needed to maintain ecosystem services. Nature, 2011; 477: 199-202. doi: 10.1038/nature10282.

[10] Jing X, Sanders N J, Shi Y, Chu H, Classen A T, Zhao K, et al. The links between ecosystem multifunctionality and above- and belowground biodiversity are mediated by climate. Nature Communications, 2015; 6: 8159. doi: 10.1038/ncomms9159.

[11] Li J, Delgado-Baquerizo M, Wang J T, Hu H W, Cai Z J, Zhu Y N, et al. Fungal richness contributes to multifunctionality in boreal forest soil. Soil Biology and Biochemistry, 2019; 136: 107526. doi: 10.1016/ j.soilbio.2019.107526.

[12] Chen Q L, Ding J, Li C Y, Yan Z Z, He J Z, Hu H W. Microbial functional attributes, rather than taxonomic attributes, drive top soil respiration, nitrification and denitrification processes. Science of the Total Environment, 2020; 734: 139479. doi: 10.1016/j.scitotenv.2020. 139479.

[13] Chen Q L, Ding J, Zhu D, Hu H W, Delgado-Baquerizo M, Ma Y B, et al. Rare microbial taxa as the major drivers of ecosystem multifunctionality in long-term fertilized soils. Soil Biology and Biochemistry, 2020; 141: 107686. doi: 10.1016/j.soilbio.2019.107686.

[14] Wang X Q, Chen X B, Zhan J C, Huang W D. Effects of ecological factors on quality of winegrape and wine. Food Science, 2006; 27: 791-797.

[15] Shi P B, Chen H J, Zhang Z W. Chemical and physical properties of soils in hillside vineyards at different altitudes. Soil, 2009; 41: 495-499.

[16] Miele A, Rizzon L A. Rootstock-scion interaction: 2. Effect on the composition of Cabernet Sauvignon grape must. Revista Brasileira de Fruticultura, 2017; 39 . doi: 10.1590/0100-29452017434.

[17] Reynolds A G, Taylor G, de Savigny C. Defining Niagara terroir by chemical and sensory analysis of Chardonnay wines from various soil textures and vine sizes. American Journal of Enology and Viticulture, 2013; 64: 180-194.

[18] Cortell J M, Halbleib M, Gallagher A V, Righetti T L, Kennedy J A. Influence of vine vigor on grape (Vitis vinifera L. cv. Pinot noir) and wine proanthocyanidins. Journal of Agricultural and Food Chemistry, 2005; 53: 5798-5808.

[19] Tardaguila J, Baluja J, Arpon L, Balda P, Oliveira M. Variations of soil properties affect the vegetative growth and yield components of "Tempranillo" grapevines. Precision Agriculture, 2011; 12: 762-773.

[20] Perkins V P. Growth and rippening of strawberry fruit. Horticultural Reviews, 1995; 17: 267-297.

[21] Zhang Z, Li H, Zhang J, Xue J, Zhang X J. Aroma characteristics of aged 'Cabernet Sauvignon' dry red wine from eastern foothill of Helan mountain Food Science, 2019; 40(18): 203-209. (in Chinese)

[22] Bremner J M, Mulvaney C S. "Nitrogen-Total" in Methods of soil analysis. Part 2. chemical and microbiological properties. eds. A. L. Page, R. H. Miller, and D. R. Keeney, American Society of Agronomy, Soil Science Society of America, Madison, Wisconsin, 1982; pp.595-624.

[23] Schade J D, Kyle M, Hobbie S E, Fagan W F, Elser J J. Stoichiometric tracking of soil nutrients by a desert insect herbivore. Ecology Letters, 2003; 6: 96-101.

[24] Wang H. Wine analysis and determination. Beijing: China Agriculture
Press, 2011; pp.118-135. (in Chinese)

[25] Kim D O, Chun O K, Kim Y J, Moon H Y, Lee C Y. Quantification of polyphenolics and their antioxidant capacity in fresh plums. Journal of Agricultural and Food Chemistry, 2003; 51(22): 6509-6515.

[26] Cliff M A, King M C, Schlosser J. Anthocyanin, phenolic composition, colour measurement and sensory analysis of $\mathrm{BC}$ commercial red wines. Food Research International, 2007; 40(1): 92-100.

[27] Caporaso J G, Kuczynski J, Stombaugh J, Bittinger K, Bushman F D, Costello E K, et al. QIIME allows analysis of high-throughput community sequencing data. Nature Biotechnology, 2010; 7: 335-336.

[28] Byrnes J E K, Gamfeldt L, Isbell F, Lefcheck J S, Griffin J N, Hector A, et al. Investigating the relationship between biodiversity and ecosystem multifunctionality: challenges and solutions. Methods in Ecology and Evolution, 2014; 5: 111-124. doi: 10.1111/2041-210X.12143.

[29] Lefcheck J S, Byrnes J E K, Isbell F, Gamfeldt L, Griffin J N, Eisenhauer $\mathrm{N}$, et al. Biodiversity enhances ecosystem multifunctionality across trophic levels and habitats. Nature Communications, 2015; 6: 6936. doi 10.1038/ncomms7936

[30] Perkins D M, Bailey R A, Dossena M, Gamfeldt L, Reiss J, Trimmer M, et al. Higher biodiversity is required to sustain multiple ecosystem processes across temperature regimes. Global Change Biology, 2015; 21(1): 396-406.

[31] Valencia E, Maestre F T, Le Bagousse-Pinguet Y, Quero J L, Tamme R, Borger L, et al. Functional diversity enhances the resistance of ecosystem multifunctionality to aridity in Mediterranean drylands. New Phytologist, 2015; 206: 660-671.

[32] Maestre F T, Quero J L, Gotelli N J, Escudero A, Ochoa V, Delgado-Baquerizo $\mathrm{M}$, et al. Plant species richness and ecosystem multifunctionality in global drylands. Science, 2012; 335: 214-218.

[33] Wang W, Buligen J, Hu X D, Xia J F, Zhang Z D, Gu M Y, et al. Analysis of the microbial community diversity of soil from wine grape productiing area in Xinjiang based on high-throughput sequencing. Xinjiang Agriculture Science, 2020; 57: 859-868. (in Chinese)

[34] Wei Y J, Zhou W, Ma W R. Microbial diversity of berries, leaves and soil of grapevine plants grown in Xinjiang analyzed by high-throughput sequencing. Food Science, 2018; 39(6): 162-170. (in Chinese)

[35] Leff J W, Jones S E, Prober S M, Barberan A, Borer E T, Firn J L, et al Consistent responses of soil microbial communities to elevated nutrient inputs in grasslands across the globe. Proceedings of the National Academy of Sciences of the United States of America, 2015; 112: 10967-10972.

[36] Blackwood C B, Waldrop M P, Zak D R, Sinsabaugh R L. Molecular analysis of fungal communities and laccase genes in decomposing litter reveals differences among forest types but no impact of nitrogen deposition. Environmental Microbiology, 2007; 9(5): 1306-1316.

[37] Curlevski N J A, Xu Z, Anderson I C, Cairney J W G. Converting Australian tropical rainforest to native Araucariaceae plantations alters soil fungal communities. Soil Biology and Biochemistry, 2010; 42(1): 14-20.

[38] Tan Y, Cui Y, Li H, Kuang A, Li X, Wei Y, et al. Rhizospheric soil and root endogenous fungal diversity and composition in response to continuous Panax notoginseng cropping practices. Microbiological Research, 2017; 194: 10-19.

[39] Cordero-Bueso G, Arroyo T, Serrano A, Tello J, Aporta I, Velez M D, et al Influence of the farming system and vine variety on yeast communities associated with grape berries. International Journal of Food Microbiology, 2011; 145(1): 132-139.

[40] Xu W, Ma Z, Jing X, He J S. Biodiversity and ecosystem multifunctionality: advances and perspectives. Biodiversity Science, 2016; 24(1): 55-71.

[41] Miki T, Yokokawa T, Matsui K. Biodiversity and multifunctionality in a microbial community: a novel theoretical approach to quantify functional redundancy. Proceedings of the Royal Society of London, Series B: Biological Sciences, 2014; 281: 20132498. doi: 10.1098/rspb.2013.2498.

[42] Tsiafouli M A, Thebault E, Sgardelis S P, de Ruiter P C, van der Putten W $\mathrm{H}$, Birkhofer $\mathrm{K}$, et al. Intensive agriculture reduces soil biodiversity across Europe. Global Change Biology, 2015; 21(2): 973-985.

[43] Govaerts B, Mezzalama M, Unno Y, Sayre K D, Luna-Guido M, Vanherck $\mathrm{K}$, et al. Influence of tillage, residue management, and crop rotation on soil microbial biomass and catabolic diversity. Applied Soil Ecology, 2007; 37: 18-30.

[44] Ochoa-Hueso R, Eldridge D J, Delgado-Baquerizo M, Soliveres S, Bowker 
M A, Gross N, et al. Soil fungal abundance and plant functional traits drive fertile island formation in global drylands. Journal of Ecology, 2017; 106(1): 242-253.

[45] Koundouras S, Hatzidimitriou E, Karamolegkou M, Dimopoulou E, Kallithraka S, Tsialtas $\mathrm{J} \mathrm{T}$, et al. Irrigation and rootstock effects on the phenolic concentration and aroma potential of Vitis vinifera $\mathrm{L}$. cv. Cabernet
Sauvignon grapes. Journal of Agricultural and Food Chemistry, 2009; 57(17): 7805-7813.

[46] Tongsiri P, Tseng W Y, Shen Y, Lai H Y. Comparison of soil properties and organic components in infusions according to different aerial appearances of tea plantations in Central Taiwan. Sustainability, 2020; 12 4384. doi: 10.3390/su12114384. 